\title{
COMPARISON OF PREVALENCE OF INTESTINAL PARASITIC INFECTIONS IN SCHOOLCHILDREN IN KUALA LUMPUR
}

\author{
Mahmood Ameen Abdulla', Khairul Anuar Abdullah', Khalifa Sidik', Salmah Ismail', Suzainur Kulop Abdul \\ Rahman', Mohamad Nazmul Hassan Mahziz' and Irwan Hamzah'
}

'Department of Allied Health Science, Faculty of Medicine, University of Malaya,50603 Kuala Lumpur, Malaysic

${ }^{2}$ Department of Parasitology, Faculty of Medicine, University of Malaya, 50603, Kuala Lumpur, Malaysia

\begin{abstract}
A comparative study was carried out to identify the prevalence of intestinal parasitic infestation among students in 3 different types of primary school located in Ampang area, Kuala Lumpur. A survey of infection rate was done from April to June 2001. Stool samples were randomly collected from one-hundred and eleven schoolchildren aged 9-12 years were examined for intestinal parasites, using a light microscope for direct smear and after concentration for formol-either method. It was found that an overall prevalence of intestinal parasite infection of schoolchildren was $51 \%$. The infection rate of males and females was $(60.3 \%)$ and $(29.2 \%)$ respectively. Prevalence seems to be higher in the younger age groups. Also, the usual intestinal parasites were found more commonly in local and foreign schools than international school. The local school had the highest prevalence $(62 \%)$, followed by the foreign school $(52 \%)$ and international school $(38.9 \%)$. The prevalence in the international school was much lower compared to the local and foreign schools. (JUMMEC 2002; 2:118-121)
\end{abstract}

KEYWORDS: Intestinal parasites, faecal samples, prevalence, schoolchildren

\section{Introduction}

Intestinal parasites are highly prevalent in developing countries because of poor living condition. Repeated surveys in recent years in many developing countries in Africa, Asia and South America showed that the problem has not improved (1). The impact of progress has been minimal in the rural areas of developing countries where the majority of population are located and are exposed to higher risk of infection.

Intestinal parasitic infections are an endemic problem worldwide.Although such infections rarely cause death, it affects nutrition, growth and development severely. Also, the problem is always skewered more to the rural areas of population, rather than urban. Children are more likely to obtain infections, compared to adults. $(2,3,4,5,6)$.

Intestinal parasitic infections are transmitted via the faecal-oral route, although sometimes it can be transmitted cutaneously (7). In tropical and sub-tropical climate countries, the more prominent intestinal parasites are Ascaris lumbricoides and Entamoeba coli $(8,9)$. Treatment is widely available especially for helminth infections, which appear in many over-the-counter drugs (10). It has been shown that treatment for worms may improve work productivity and overall health. Interventions that helped protein-energy malnutrition or iron-deficiency anaemia also resulted in improved physical fitness, work capacity and productivity $(9,11)$.

Intestinal parasites are common in Malaysia especially among the children below the age of 15 years. Studies have shown that the prevalence rate is particularly high among the rural and urban squatter population $(12,13)$. Malaysia is a developing nation. It is constantly trying to better itself to become one of the developed nations of the world. One aspect in this vision is to better the living conditions of the people. Although such efforts have been successful with middle and upper class societies, it has not been so for the lower class society (8). Other environmental factor that must be pointed out is the source of clean water, availability of proper toilets, roads, drainage systems, lower socio-economic status, poor personal hygiene and lack of proper sanitary and garbage disposal $(14,15)$.

\section{Correspondence.}

Mahmood Ameen Abdull?

Department of Allied Health Science, Faculty of Medicine.

University of Malaya.

50603 Kuala Lumpur, Malaysia 
The present survey was conducted to determine the prevalence and types of intestinal parasitic infections among the three different primary schoolchildren in Ampang, Kuala Lumpur, Malaysia and to observe any relationship between the prevalence rate calculated and the type of school the student attended.

\section{Materials and Methods}

\section{Area of study}

The area of study is in Ampang. Ampang is a large geographical area and has a wide range of communities with varying socio-economic status.

\section{Schools studied}

Three types of schoolchlidren were studied, each representing distinct social and economic backgrounds; the government school, the international school and the foreign school. I I I samples were obtained for this study. 50 samples were from the local school, 36 samples from the international school and 25 samples from the foreign school. The study population consists of 73 males and 48 females, their ages ranging from nine years to twelve years

\section{Sample collection}

Faecal samples were taken using standard brown-capped $60 \mathrm{ml}$ faeces containers filled with approximately $20 \mathrm{ml}$ of $10 \%$ formalin solution. The participating students were given necessary instructions. The studied age group was between age 9 and 12 .

\section{Reagents used}

The reagents used were Lugol's iodine, normal saline, ether and formaldehyde. Lugol's iodine was used as a stain to help differentiate helminth eggs and protozoan cysts from artefacts. Normal saline helps in visualising protozoan trophozoites. When viewed with correct contrast, protozoan trophozoites will appear more refractive. Formaldehyde is used in transportation of the faecal samples, as a preservative. It is also used with ether in the formol-ether sedimentation method, where parasites from a large amount of faeces are concentrated into a much smaller amount and then viewed under the microscope.

\section{Results}

The prevalence and distribution of intestinal parasites among three different schoolchildren in Ampang are shown in Tablel,2 and 3. In general, the overall prevalence was found to be $51 \%$. In the local school, foreign school and international school the prevalence was found to be $62 \%, 52 \%$ and $38.9 \%$ respectively.
Table I shows the breakdown of the types of parasites present in the local school and is divided into two main categories, age and sex. The figures show the number of positive samples. The numbers in parenthesis indicate the total samples and those in italic are the prevalence in percentage. For the foreign school, much broader age groups participated (Table 2). The age group with the highest prevalence was in age 9. Age 12 had the lowest prevalence. For the international school, ages 9 to II were studied. From Table 3 , age 9 had the highest prevalence. Age II had the lowest. Table 4 shows the tabulated data from all three schools, with 4 age groups. The age group with the highest prevalence is age 9 . The prevalence seems to decrease with age as age 12 has the lowest prevalence.

An interesting find was a particular helminth, Dipylidium coninum. This helminth is not a natural parasite of man, but a natural parasite of dogs that can cause a zoonotic infection.

\section{Discussion}

Infection rates for intestinal parasites was quite high among the three different schoolchildren studied. In general, the present study demonstrates that there were not much differences in prevalence between the local (62\%) and foreign school (52\%). However, when comparing these results to the prevalence in the international school, the international school fared much better $(38.9 \%)$. International schoolchildren has significantly lower prevalence rate than the local and foreign schoolchildren.Therefore, it seems that the type of school the schoolchildren attended may have an effect on the prevalence of intestinal parasitic infections. International schools have higher operational costs; therefore the school must have better food preparation, cleaner studying environment and good sanitation. The student's overall health is also much better.

Another point to look at was the low prevalence level of one helminth, Ascaris lumbricoides. One reason for this is the availability of numerous over-the-counter deworming medications $(8,9)$. Prevalence of Trichuris trichiura was also very low. One good reason for this is that this worm is more prominent in the rural areas, especially in estate plantations $(14,16)$.

Perhaps, a follow-up study can be done, as there have not been any such studies lately. Other health measures include better systems for disposal of faeces in the ru$\mathrm{ral}$ areas $(8,9)$. Development and distribution of cheap deworming medicine that is effective against a wider array of helminths would be helpful. This is important, as the direct benefit of drug therapy is that the worm burden is removed, which reduces morbidity and may reduce the rate of transmission $(11,17)$. An improvement on the environmental side of the problem is also a good step to enforce. Proper toilets and good water supply should be emphasised $(14,16)$. 
Table I. Distribution of parasites in local schoolchildren by age and sex

\begin{tabular}{lccccc}
\hline Parasite & \multicolumn{2}{c}{ Age } & & \multicolumn{2}{c}{ Sex } \\
\cline { 2 - 3 } \cline { 5 - 6 } & $10(26)$ & $11(24)$ & & Male (44) & Female (6) \\
\hline $\begin{array}{l}\text { Enterobius } \\
\text { vermicularis }\end{array}$ & 3 & 0 & 3 & 0 \\
$\begin{array}{l}\text { Taenia spp. } \\
\begin{array}{l}\text { Ascaris } \\
\text { lumbricoides }\end{array}\end{array}$ & 0 & 1 & & 1 & 0 \\
$\begin{array}{l}\text { Strongyloides } \\
\text { stercorallis }\end{array}$ & 2 & 5 & 6 & 1 \\
$\begin{array}{l}\text { Dipylidium } \\
\text { caninum }\end{array}$ & 2 & 0 & & 2 & 0 \\
$\begin{array}{l}\text { Entamoeba } \\
\text { histolytica } \\
\text { Entamoeba }\end{array}$ & 4 & 6 & & 8 & 2 \\
colic & 2 & 5 & & 7 & 0 \\
\begin{tabular}{l} 
Uninfected \\
\hline Totals
\end{tabular} & 13 & 6 & 17 & 2 \\
\hline
\end{tabular}

Table 3. Distribution of parasites in international schoolchildren by age and sex

\begin{tabular}{|c|c|c|c|c|c|}
\hline \multirow{2}{*}{ Parasite } & \multicolumn{3}{|c|}{ Age } & \multicolumn{2}{|c|}{ Sex } \\
\hline & $\begin{array}{c}9(8) \\
.\end{array}$ & $10(19)$ & II(9) & $\begin{array}{r}\text { Male } \\
(20)\end{array}$ & $\begin{array}{c}\text { Female } \\
(16)\end{array}$ \\
\hline $\begin{array}{l}\text { Enterobius } \\
\text { vermicularis }\end{array}$ & 1 & 1 & 0 & 1 & 1 \\
\hline $\begin{array}{l}\text { Ascaris } \\
\text { lumbricoides }\end{array}$ & 1 & 1 & 0 & 2 & 0 \\
\hline $\begin{array}{l}\text { Strongyloides } \\
\text { stercorallis }\end{array}$ & 2 & 1 & 1 & 2 & 2 \\
\hline $\begin{array}{l}\text { Dipylidium } \\
\text { caninum }\end{array}$ & 0 & 1 & 0 & 0 & 1 \\
\hline $\begin{array}{l}\text { Entamoeba } \\
\text { histolytica }\end{array}$ & 3 & 0 & 0 & 2 & 1 \\
\hline $\begin{array}{l}\text { Entamoeba } \\
\text { colic }\end{array}$ & 1 & 1 & 0 & 2 & 0 \\
\hline Uninfected & 0 & 14 & 8 & 11 & 11 \\
\hline Totals & $8(100 \%)$ & $5(26 \%)$ & $1(11.1 \%)$ & $9(45 \%)$ & $5(31.3)$ \\
\hline
\end{tabular}

Table 2. Distribution of parasites in foreign schoolchildren by age and sex

\begin{tabular}{|c|c|c|c|c|c|c|}
\hline \multirow{2}{*}{ Parasites } & \multicolumn{4}{|c|}{ Age } & \multicolumn{2}{|c|}{ Sex } \\
\hline & $9(5)$ & $10(7)$ & $11(5)$ & $12(8)$ & Male (20) & Female(16) \\
\hline Ascaris lumbricoides & 1 & 1 & 0 & 0 & 2 & 0 \\
\hline Strongyloides stercorallis & 2 & 1 & 2 & 0 & 2 & 3 \\
\hline Trichuris trichiura & 0 & 1 & 0 & 0 & 1 & 0 \\
\hline Entamoeba histolytica & 1 & 0 & 1 & 2 & 2 & 2 \\
\hline Entamoeba colic & 1 & 0 & 0 & 0 & 1 & 0 \\
\hline Uninfected & 0 & 4 & 2 & 6 & 1 & 11 \\
\hline Totals & $5(00 \%)$ & $3(42.8 \%)$ & $3(60 \%)$ & $2(25 \%)$ & $8(88.9 \%)$ & $5(31.3 \%)$ \\
\hline
\end{tabular}

Table 4. Distribution of parasites by age and sex

\begin{tabular}{lccccccc}
\hline \multirow{2}{*}{ Parasites } & \multicolumn{3}{c}{ Age } & \multicolumn{3}{c}{ Sex } \\
\cline { 2 - 5 } \cline { 6 - 7 } & $9(5)$ & $10(7)$ & $11(5)$ & $12(8)$ & Male (20) & Female(16) \\
\hline Entrobius vermicularis & 1 & 4 & 0 & 0 & 4 & 1 \\
Tania spp. & 0 & 0 & 1 & 0 & 1 & 0 \\
Ascaris lumbricoides & 2 & 2 & 1 & 0 & 4 & 1 \\
Strongyloides stercorallis & 4 & 4 & 8 & 0 & 10 & 6 \\
Dipylidium caninum & 0 & 2 & 0 & 0 & 2 & 0 \\
Trichuris trichiura & 0 & 2 & 0 & 0 & 1 & 1 \\
Entamoeba histolytica & 4 & 4 & 7 & 2 & 12 & 5 \\
Entamoeba colic & 2 & 3 & 5 & 0 & 101 & 0 \\
Uninfected & 0 & 31 & 16 & 6 & 29 & 24 \\
\hline Totals & $13(00 \%)$ & $21(40.4 \%)$ & $22(57.9 \%)$ & $2(25 \%)$ & $44(60.3 \%)$ & $14(29.2 \%)$ \\
\hline
\end{tabular}




\section{References}

I. WHO. Intestinal protozoan and helminthic infections. World Health Organization Technical Report Series, 1981; 1665.

2 Gupta MC, Mithal S, Arora KL and Tandon BN. (1977). Effect of periodic deworming on nutritional status of Ascaris-infested preschool children receiving supplementary food. Lancet 1977; 2: 108-110.

3. Al-Eissa YA, Assuhaimi, SA, Abdullah AM, AboBaker AM, Al-Husain MA, Al-Nasser $M N$ and Al-Borno MK. Prevalence of Intestinal Parasites in Saudi Children: a Community-based Study. J.Trop Ped 1995; 41 (1): 47-49.

4. Oberhelman RA, Guerrero ES, Fernadez ML and Mera RC. Correlations between intestinal parasitosis, physical growth, and psychomotor development among infants and children from rural Nicaragua. Am J Trop Med Hyg 1998; 58(4): 470-475.

5. Perez E. Intestinal parasite infections and schistosomiasis in a poor urban area, in townships of the sugar cane belt and in villages of the semi-arid area of Northeast Brazil. Cahiers d'études et de recherches francophones. 2000; 10(2): 127-129.

6. Lee KJ, Ahn YK and Ryang YS. (2001). Enterobius vermicularis egg positive rates in primary school children in Gangwon-do (province), Korea. Korean J Parasitol 200I; 39(4): 327-328.

7. Jeffrey $\mathrm{HC}$ and Leach RM.Atlas of medical helminthology and protozoology. E\&S Livingstone, 1966.

8. Rajeswari B. Sinniah B and Hussein H. Socio-economic factors associated with intestinal parasites among children living in Gombak, Malaysia.Asia-Pacific J of Public Health 1994: $7(1): 21-25$
9. Al-Agha $\mathrm{R}$ and Teodorescu I. Intestinal parasites infestation and anemia in primary schoolchildren in Gaza Governorate-Palestine. Roum Arch Microbiol Immunol 2001; 59(1-2): 131-143.

10. Leventhal R and Cheadle RF. Medical Parasitology:A Selfinstructional text. $2^{\text {nd }}$ edition. Philadelphia: F.A. Davis Company, 1985.

II. Stephenson, L.S, Latham, M.C. Kurz, K.M, Kinoti, S.N and Brigham, H. (1990). Improvements in physical fitness of Kenyan schoolboys infected with hookworm, Trichuris trichiura and Ascaris lumbricoides following a single dose of albendazole. Trans Roy Soc Trop Med Hyg., 84: 277-282.

12. Kan SP. Soil transmitted helminthiasis in Selangor, Malaysia. Med Malaysia 1982; 37: 180-190

13. Sinniah B and Chew PI.Treatment of intestinal nematodes with albendazol. Tropl Biomed 1988; 5: 47-50.

14. Kan SP. Soil-transmitted helminthiases in Malaysia. A socioeconomic and public health problem. Public Health Rev 1988; 16:127-147.

15. Katz DE and Taylor DV. (200I). Parasitic infections of the gastrointestinal tract. Gastroenterol Clin North Amer 2001; 30(3): 797-815.

16. Nwabuisi C. Childhood cryptosporidiosis and intestinal parasitosis in association with diarrhoea in Kwara State, Nigeria. West Afr J Med 200I; 20(2): 165-168.

17. Bouratbine A,Aoun K, Sial E, Chahed MK, Ben Hassine L and Meherzi A. (2000). For a better estimation of the prevalence of intestinal parasitism in the Tunis region. Bull Soc Pathol Exot 2000; 93(5): 353-355. 